\title{
ACPP Antibody
}

National Cancer Institute

\section{Source}

National Cancer Institute. ACPP Antibody. NCI Thesaurus. Code C112058.

Any immunog lobulin that recognizes prostatic acid phosphatase. 